\title{
Learning Anywhere, Anytime: Student Motivators for M-learning
}

\author{
Romana Martin \\ Curtin University, \\ Perth, WA, Australia
}

Romana.Martin@curtin.edu.au

\author{
Tanya McGill and \\ Fay Sudweeks \\ Murdoch University, \\ Perth, WA, Australia
}

\section{T.Mcgill@murdoch.edu.au F.Sudweeks@murdoch.edu.au}

\section{Executive Summary}

This paper documents the outcomes of a study that focused on identifying what motivates students to use mobile devices for learning and to engage in m-learning. An outcome of this study was to provide a better understanding of what educators should consider when adapting their course for mobile learners. The research included seven classes from three Australian universities. The students in this study used laptops or tablet PCs, and in three of the classes, these were provided by the university as part of a laptop/tablet program. The findings indicated that mobility was the key motivator for the use of laptops, and the learning tasks that students found to be most motivating involved accessing information, authoring (e.g., writing, blogging, note taking) and communication. .

Keywords: Motivation, motivators, m-learning, mobile learning, engagement.

\section{Introduction}

M-learning transcends the barriers between in-class and out-of-class experiences with opportunities for anywhere anytime learning and the potential for students to participate in educational activities beyond the limitations of traditional study environments. Hence there exists an expectation that, with access to mobile technologies and the presence of adequate wireless infrastructure, students can become effectively engaged in m-learning and that this will be of benefit to their overall learning experience (Cobcroft, Towers, Smith, \& Bruns, 2006; Corbeil, Pan, Sullivan, \& Butler, 2007; Gulek \& Demirtas, 2005; Kim, Mims, \& Holmes, 2006; Traxler 2009).

In order for students to become engaged in m-learning, some self-direction in learning is required whereby students are motivated to participate in learning related activities that extend beyond the boundaries of teacher direction and formal classes. For instance, Sha, Looi, Chen, and Zhang

Material published as part of this publication, either on-line or in print, is copyrighted by the Informing Science Institute. Permission to make digital or paper copy of part or all of these works for personal or classroom use is granted without fee provided that the copies are not made or distributed for profit or commercial advantage AND that copies 1) bear this notice in full and 2) give the full citation on the first page. It is permissible to abstract these works so long as credit is given. To copy in all other cases or to republish or to post on a server or to redistribute to lists requires specific permission and payment of a fee. Contact Publisher@InformingScience.org to request redistribution permission.
(2012) suggest that the characteristics of mobile learning (i.e., enabling studentcentered, personal, and ubiquitous learning) provide conditions for learning anywhere and anytime, but also require learners to be motivated and to self-regulate their learning. To foster self-directed and self-regulated learning, a shift is required from teacher- and content-centered learning towards more student-centered learning environments 
where, consequently, learners become responsible for their learning and the involvement and participation necessary for their learning (Ingleton, Kiley, Cannon, \& Rogers, 2000).

\section{Literature Review}

For educators it is increasingly important to understand the motivators that encourage student learning and use of mobile devices for learning purposes. According to Garrison (1997), motivation is a key factor in self-directed learning as students are required to assume personal responsibility for both managing and monitoring their learning processes and construction of learning. However, Seifert and O'Keefe (2001) stressed that students need to feel confident, have a sense control over their learning, and consider the learning activities to be meaningful and relevant, for the effects of motivation to be maximised. Additionally, Martin (2006, p. 73) suggested that motivation and engagement both have a significant role in students' study, providing the energy and drive to work effectively, learn, and achieve to their potential.

Often it is assumed that students will be naturally motivated to use mobile devices for learning. For instance, Laurillard (2007, p.156) stated that "m-learning is an activity that is intrinsically motivating for students by providing: control over learning goals, ownership, fun, communication, learning in contexts, and continuity between contexts". Furthermore, Roblyer and Doering (2010) suggest that integrating new technologies in ways that are meaningful for students and align with their motivations and goals is likely to generate further motivation to learn. However, without an investigation of what students believe motivates them to use mobile devices for m-learning, there can be little certainty as to whether this occurs spontaneously or whether there are specific motivators that prompt students to engage in m-learning.

According to Keller (2008) and MacCallum (2009), m-learning students need to be motivated not only to learn, but also motivated to use mobile devices to support their learning. This was evident in earlier studies in which high levels of student (and teacher) motivation were linked with successful implementation of laptops in learning (e.g. Hall \& Elliott, 2003; McMillan \& Honey, 1993; Newhouse, 2001; Oloruntoba, 2006).

Motivation has also been linked with goal orientation and a focus on learning achievements (Klein, Noe \& Wang, 2006; Pintrich \& Schunk, 2002; Schunk, Pintrich \& Meece, 2008; Wolters, 2004). Wolters, Yu, \& Pintrich (1996) described goal orientation as an integrated pattern of beliefs that leads to different ways of approaching, engaging in, and responding to achievement situations, and, according to Pintrich (2003), both motivation and goal orientation are the reasons for students engaging in achievement behaviours. Students' learning goal orientation, as found by MacCallum (2009), is closely linked with intrinsic motivation. Students who have a learning goal orientation and are intrinsically motivated are more likely to adopt new technologies, enjoy learning about the technologies and, consequently, develop more confidence in using technologies. MacCallum (2009) identified that students who were experienced with using computers were also likely to be goal oriented and independent learners, characteristics that resulted in students adopting new technologies. Goal orientation may encompass intrinsically motivated learning goals (e.g., mastering new knowledge) and extrinsically motivated performance goals (e.g., grades). Therefore, students' motivation to use laptops and mobile devices is likely to have an impact on their engagement in m-learning and on students achieving their learning goals.

Additionally, Boekaerts (2001) stressed that students' motivation is context sensitive and highlighted the importance of considering situated motivation in the learning environment, that is, what students consider motivating or demotivating in their specific context. Furthermore, Breen and Lindsay (2002) found that students may require different motivators that are not necessarily linked to achievement goals, and this may vary depending on their discipline area. In their study, 
students in the disciplines of computing, history, biology, and geology were motivated more by the enjoyment of learning experiences than by the pursuit of learning goals.

Some studies have indicated that technological innovations are likely to be embraced by students more so than by lecturers (Conole, de Laat, Dillon \& Darby, 2008; Lane \& Yamashiro, 2005; MacCallum \& Jeffrey, 2010; Roberts, 2005) and that the motivation of lecturers to embrace technologies can also influence students' perceptions of using the technologies to support their learning (Kuo, 2005). Likewise, Demb, Erickson \& Hawkins-Wilding (2004) and MacCallum and Jeffrey (2009) identified that one of the major factors affecting student perceptions of the value of laptops to their academic success was their lecturer's motivation to use mobile devices and the quality of their lecturer's use of the technology for teaching.

In an early laptop study, McMillan and Honey (1993, p. 2) identified that positive experiences of using laptops were supported by "a high level of student and teacher motivation, the role of the teacher in facilitating and encouraging students' active appropriation of the technology and a steady increase in the technological competencies among the teachers". Other researchers (e.g., Hall \& Elliott, 2003; Herrington, Herrington, Mantei, Olney, \& Ferry, 2009; MacCallum \& Jeffrey, 2010; Newhouse, 2001; Oloruntoba, 2006), due to similar findings, recommended professional development to support teaching in m-learning environments as a necessary prerequisite for successful m-learning.

The literature revealed a complex interplay of factors that may affect students' motivation to use mobile devices for learning and highlights the need for further understanding of what motivates students to engage in m-learning. Hence the research described in this paper aimed to identify the motivators that lead to students' use of m-learning devices. The research question addressed was: What motivates students to use their laptops for m-learning?

Awareness of the motivators that encourage students' use of m-learning devices will inform educators on aspects of mobile learning that are significant to students and should assist educators in designing learning experiences that meet students' needs.

\section{Methodology}

As part of a larger study on m-learning, and based on the literature on m-learning and guidelines for survey design (de Vaus, 2002), survey questions were developed to explore students' motivators to use laptops and engage in m-learning. In this study, which commenced in 2008, $\mathrm{m}$-learning was defined as learning that takes place in a variety of contexts, within and beyond traditional learning environments, utilising any type of mobile device.

Although some aspects of motivation, or possible motivators, were embedded in several items throughout the survey, two specific items were included to establish specific motivators. The first question asked the students what motivated them to use their laptops. The second question asked the students whether the learning activities in their current subject engaged and motivated them to study. For each of these questions an optional field was included for text-based input.

Classes from three different universities - Edith Cowan University (ECU), Charles Darwin University (CDU), and Murdoch University (MU) - were selected based on predefined criteria:

1. subject offered as part of an undergraduate course at university;

2. students in the subjects were either participants in a laptop or tablet program or the subject was identified as involving above average formal or informal student use of laptops or tablet computers;

3. subject offered students access to a LMS providing online learning resources or activities; and 
4. reliable availability for participation in the study in the first teaching period of the year.

On the basis of the above criteria approximately ten possible classes were identified; however, the selection method was both purposeful and convenience sampling as the study was limited to the range of classes available at the time of the study and the willingness of Program Directors, Course Coordinators to support the study. Only seven classes sourced from three Australian universities met the required criteria (Table 1).

Table 1: Summary of classes included in the study

\begin{tabular}{c|l|c|c|c}
\hline Class & \multicolumn{1}{|c|}{ Subject } & Discipline Area & $\begin{array}{c}\text { m-learning pro- } \\
\text { gram }\end{array}$ & University \\
\hline 1 & Becoming Multi Literate & Education & $\begin{array}{c}\text { Laptop program } \\
24 / 7 \text { access }\end{array}$ & ECU \\
\hline 2 & The Mobile Web & IT & $\begin{array}{c}\text { Tablet PC pro- } \\
\text { gram with in-class } \\
\text { access }\end{array}$ & CDU \\
\hline 3 & $\begin{array}{l}\text { Human Computer Interac- } \\
\text { tion Design }\end{array}$ & IT & $\begin{array}{c}\text { Tablet PC pro- } \\
\text { gram with in-class } \\
\text { access }\end{array}$ & CDU \\
\hline 4 & $\begin{array}{l}\text { Introduction to Information } \\
\text { Technology }\end{array}$ & IT & $\begin{array}{c}\text { Ad hoc use of } \\
\text { laptops/tablets }\end{array}$ & MU \\
\hline 5 & $\begin{array}{l}\text { Introduction to Multimedia } \\
\text { and the Internet }\end{array}$ & IT & $\begin{array}{c}\text { Ad hoc use of } \\
\text { laptops/tablets }\end{array}$ & MU \\
\hline 6 & $\begin{array}{l}\text { Systems Analysis and De- } \\
\text { sign }\end{array}$ & IT & $\begin{array}{c}\text { Ad hoc use of } \\
\text { laptops/tablets }\end{array}$ & MU \\
\hline 7 & Business Associations Law & Law & $\begin{array}{c}\text { Ad hoc use of } \\
\text { laptops/tablets }\end{array}$ & MU \\
\hline
\end{tabular}

These classes were selected as the expected use or ownership of laptop or tablet computers was likely to be higher than average. Class 1 from ECU and Classes 2 and 3 from CDU were classes in which laptop loan programs (m-learning programs) were in place and therefore all of the students had access to laptops or tablet computers. The laptop program at ECU provided all firstyear Bachelor of Education students with a free loan of a wireless laptop for use throughout their first year of study. Students participating in this program were provided with an initial orientation to using the laptops and wireless network, access to support services for hardware and software issues, and were encouraged to use the laptops $24 / 7$ for both learning and recreational purposes. In contrast, the tablet program at CDU was classroom-based and students were required to copy their work to other devices for use out of class. Classes 4 to 7 from MU did not have a laptop program. In these units, students were invited to participate in the study only if they used laptop or tablet computers for study purposes. Table 2 shows the total enrolment numbers in each of the classes and the percentage of students in the unit who participated based on enrolment numbers. The laptop users were known in Classes 1, 2 and 3; however, the number of laptop users could not be established in Classes 4 to 7 as information about ownership was not available. In Classes 4 to 7, student laptop owners and users self-selected by volunteering to participate in the survey. Overall, 199 students consented to participate in the study and completed the student survey.

Across all groups there were 108 (54.3\%) students in the IT discipline group and 91 (45.7\%) students were enrolled in non-IT disciplines. Participation and non participation in m-learning pro- 
grams was almost equally balanced with $100(50.3 \%)$ of students participating in m-learning programs and 99 (49.7\%) of students not participating in an m-learning program.

The survey was developed and administered through a commercial online survey tool, SurveyMonkey (www.surveymonkey.com) and initially pilot tested by six students.

The students in each class were invited via email or a message via their learning management system (LMS) site to participate in the survey.

Table 2: Percentage participating in case studies

\begin{tabular}{c|l|r|r|c}
\hline Class & \multicolumn{1}{|c|}{ Subject } & $\begin{array}{c}\text { Enrolments } \\
\text { Total }\end{array}$ & Participants & $\begin{array}{c}\text { Percentage } \\
\text { participated }\end{array}$ \\
\hline 1 & Becoming Multi Literate & 203 & 81 & $39.9 \%$ \\
\hline 2 & The Mobile Web & 55 & 14 & $25.5 \%$ \\
\hline 3 & $\begin{array}{l}\text { Human Computer Interaction } \\
\text { Design }\end{array}$ & 27 & 5 & $18.5 \%$ \\
\hline 4 & $\begin{array}{l}\text { Introduction to Information } \\
\text { Technology }\end{array}$ & 248 & 32 & $12.9 \%$ \\
\hline 5 & $\begin{array}{l}\text { Introduction to Multimedia } \\
\text { and the Internet }\end{array}$ & 108 & 21 & $19.4 \%$ \\
\hline 6 & Systems Analysis and Design & 112 & 36 & $32.1 \%$ \\
\hline 7 & Business Associations Law & 197 & 10 & $5.1 \%$ \\
\hline & Total & 950 & 199 & $20.9 \%$ \\
\hline
\end{tabular}

Completion of the survey was voluntary and anonymous, and took approximately 15 minutes. As an incentive, students were offered the chance to win a prize of an Apple iPod ${ }^{\circledR}$. The research questions were explored by analysing the data qualitatively using QSR NVivo ${ }^{\text {TM }}$ 8.0.

\section{Results}

\section{Demographics}

Participants ranged in age from 18 to 57 years (with an average age of 23.8). The majority of participants were in the $<20$ and 20-24 age groups (71.3\%). Students in this age range are often described in the literature as the Net Generation (Oblinger \& Oblinger, 2005) or Digital Natives (Prensky, 2001). The 40 and over age group represented less than 5\% of the sample and only a quarter of the participants were in the 25 to 39 age groups. $64 \%$ of the participants were female and the gender distribution varied in classes, with female participants predominantly in the education discipline.

Almost all of the students (96\%) considered themselves to be experienced or very experienced computer users, and $91.4 \%$ indicated that they owned their laptop or tablet computer. When asked about in-class use of their laptops, $20.4 \%$ of participants indicated that they always used a laptop/tablet computer in lectures or tutorials, $38.8 \%$ only sometimes, whereas $41.3 \%$ of the students reported that they have never used their laptops in class. The Education students reported the lowest level of in class use of their laptops, which was explained by the fact that many of their classes were scheduled in computer laboratories, and they therefore used laboratory PCs instead of their laptops. 


\section{Results - Motivators}

The first question asked the students about their motivation for using laptops. Table 3 shows the responses based on the options provided.

Table 3: Motivators for use of laptops for m-learning across all classes

\begin{tabular}{l|c|c}
\hline \multicolumn{1}{c|}{ Motivators } & $\begin{array}{c}\text { Frequency } \\
(\mathbf{N = 1 9 9 )}\end{array}$ & $\%$ \\
\hline Access to information on the web & 138 & $69.3 \%$ \\
\hline Access to learning resources & 134 & $67.3 \%$ \\
\hline Communication with friends & 107 & $53.8 \%$ \\
\hline Better grades & 64 & $32.2 \%$ \\
\hline Other & 25 & $12.6 \%$ \\
\hline
\end{tabular}

The main motivators for using laptops for m-learning were: access to information on the web, access to learning resources, and communication with friends. Only a third of the students were motivated by better grades.

Motivators varied by cases and a comparison of classes is summarised in Table 4. For example, in Classes 4 and 5 (IT) and Class 7 (Education), students were motivated by achieving better grades $(>40 \%)$ more so than other groups. The students least motivated by achieving better grades were in an IT subject, Class 3 , with none of the students selecting this option, yet this group was highly motivated by accessing learning resources $(80 \%)$ and information on the web (100\%). Class 2 (IT) and Class 7 (Law) had the least focus on communication with friends as a motivator for using their laptops.

Table 4: Motivators for use of laptops for m-learning by class

\begin{tabular}{l|c|c|c|c|c}
\hline \multirow{2}{*}{ Classes } & \multicolumn{5}{|c}{ Motivator } \\
\cline { 2 - 6 } & $\begin{array}{c}\text { Better } \\
\text { grades }\end{array}$ & $\begin{array}{c}\text { Access to learn- } \\
\text { ing resources }\end{array}$ & $\begin{array}{c}\text { Communication } \\
\text { with friends }\end{array}$ & $\begin{array}{c}\text { Access to in- } \\
\text { formation on } \\
\text { the web }\end{array}$ & Other \\
\hline $\begin{array}{l}\text { Class 1 - Law } \\
(\mathrm{N}=81)\end{array}$ & $35.8 \%$ & $66.7 \%$ & $45.7 \%$ & $63.0 \%$ & $11.1 \%$ \\
\hline $\begin{array}{l}\text { Class 2 - IT } \\
(\mathrm{N}=14)\end{array}$ & $14.3 \%$ & $28.6 \%$ & $28.6 \%$ & $28.6 \%$ & $0.0 \%$ \\
\hline $\begin{array}{l}\text { Class 3 - IT } \\
(\mathrm{N}=5)\end{array}$ & $0.0 \%$ & $80.0 \%$ & $40.0 \%$ & $100.0 \%$ & $20.0 \%$ \\
\hline $\begin{array}{l}\text { Class 4- IT } \\
(\mathrm{N}=32)\end{array}$ & $40.6 \%$ & $87.5 \%$ & $84.4 \%$ & $96.9 \%$ & $12.5 \%$ \\
\hline $\begin{array}{l}\text { Class 5 - IT } \\
(\mathrm{N}=21)\end{array}$ & $42.9 \%$ & $76.2 \%$ & $71.4 \%$ & $81.0 \%$ & $9.5 \%$ \\
\hline $\begin{array}{l}\text { Class 6 - IT } \\
(\mathrm{N}=36)\end{array}$ & $19.4 \%$ & $58.3 \%$ & $58.3 \%$ & $69.4 \%$ & $19.4 \%$ \\
\hline $\begin{array}{l}\text { Class 7 - Edu- } \\
\text { cation (N=10) }\end{array}$ & $40.0 \%$ & $70.0 \%$ & $10.0 \%$ & $50.0 \%$ & $20.0 \%$ \\
\hline
\end{tabular}

Note: Each instance is calculated as a \% of the total pool of students in that class study. This was a multiresponse question and therefore percentages do not add up to 100 . 
In addition to the five specified response options, there was the opportunity for students to provide further text-based information. The text responses were content analysed yielding more than one theme per response. Analyses of the qualitative data related to this question resulted in the identification of the themes shown in Table 5. There was some overlap with the motivators in the multi-answer question (e.g., access to learning resources, using the Internet, and researching) reinforcing the importance of laptops providing access to sources of information to support learning.

The major themes that emerged from these other motivators were mobility, study anytime, and access to learning resources. The most frequently mentioned of these was mobility. Students clearly valued the mobility and freedom that their laptops provided, which enabled them to study and communicate with others anywhere. Having their personal laptop with them at any time also eliminated the need to continually transfer data between computers in different locations.

Table 5: Students' motivators for using laptops

\begin{tabular}{l|c|c}
\hline \multicolumn{1}{c|}{ Motivator Themes } & $\begin{array}{c}\text { Frequency } \\
(\mathbf{N = 3 3 )}\end{array}$ & \% \\
\hline Mobility & 11 & 33.3 \\
\hline Study anytime & 8 & 24.2 \\
\hline Access to learning resources & 4 & 12.1 \\
\hline Entertainment & 3 & 9.1 \\
\hline Note taking & 3 & 9.1 \\
\hline Working on assignments & 2 & 6.1 \\
\hline Being organised & 2 & 6.1 \\
\hline Communication with lecturers & 2 & 6.1 \\
\hline Multiple uses & 2 & 6.1 \\
\hline Connecting with friends & 1 & 3.0 \\
\hline Using the Internet & 1 & 3.0 \\
\hline Online discussion & 1 & 3.0 \\
\hline Researching & 1 & 3.0 \\
\hline Using software & 1 & 3.0 \\
\hline Writing & 1 & 3.0 \\
\hline
\end{tabular}

The mobility theme is supported by the participants' comments. [The comments are coded to identify discipline type (IT, non-IT), m-learning program ( $\mathrm{P}=$ laptop program, $\mathrm{NP}=$ no program), gender $(\mathrm{M}=$ male, $\mathrm{F}=$ female), and identity number (1-199). All participant comments are presented verbatim.]

Portable, can work anytime because you can take it anywhere. (non-IT, $\mathrm{P}, \mathrm{F}, 39)$

I can do and access my work directly, instead of carrying information around on a thumbdrive or other mobile storage devices which are easier to lose. (IT, NP, M, 158)

The freedom of using it anywhere. (IT, NP, M, 182)

The second theme, being able to study anytime, revealed that students appreciated that having a laptop enables convenient access to their university work and information whenever needed. 
Being able to use my lap top for all purposes and study when i need to. (non-IT, P, F, 2)

We have one computer at home that has to be shared between three people in high school, myself and two upper primary school students so I use my laptop to actually be able to use a computer whenever I need to. (non-IT, P, F, 61)

The third most frequently mentioned theme, being able to access to learning resources, showed that students valued that their laptop supports access to both formal study resources and the Internet for study purposes.

Online journal articles from my university, discussion board, lecturer information and other resources posted by lecturers. (non-IT, P, F, 19)

The ability to have the worlds information at my fingure tips. (IT, NP, $\mathrm{M}, 157)$

The less frequently mentioned themes included study-oriented motivators such as note taking, working on assignments, being organised, communicating with lecturers, using the Internet, online discussion, researching, using software, and writing. However, other motivators were oriented more towards social and leisure uses (e.g., entertainment, connecting with friends) and some responses were very general in nature (e.g., being motivated by multiple uses of laptops).

The second multiple choice question with optional text based responses asked students whether the learning activities in their course engaged and motivated them to study. The results showed that almost $65 \%$ of the students agreed that they were motivated by learning activities, $27.3 \%$ provided a neutral response, and $7.5 \%$ of the students disagreed. The text-based responses to this question provided further insights into the motivators and demotivators of engagement in learning, as perceived by the students. The results of the content analysis were the themes shown in Table 6 for aspects that were motivating and Table 7 for the demotivators.

Table 6: Motivators for engagement in m-learning

\begin{tabular}{l|c|c}
\hline \multicolumn{1}{c|}{ Motivator Themes } & $\begin{array}{c}\text { Frequency } \\
(\mathbf{N = 4 0 )}\end{array}$ & $\%$ \\
\hline Practical tasks & 6 & 15.0 \\
\hline Interesting and relevant content & 5 & 12.5 \\
\hline Assignment tasks & 3 & 7.5 \\
\hline Real-world tasks & 3 & 7.5 \\
\hline Excitement about learning & 2 & 5.0 \\
\hline Interacting with other students & 2 & 5.0 \\
\hline Teaching styles & 2 & 5.0 \\
\hline Study guidance & 2 & 5.0 \\
\hline Understanding new concepts & 2 & 5.0 \\
\hline Learning essential skills & 1 & 2.5 \\
\hline Lectures and tutorials & 1 & 2.5 \\
\hline
\end{tabular}

The major themes for motivators that emerged from this question were: practical tasks, interesting and relevant content, assignment tasks, and real-world tasks. Example comments on practical tasks include: 
Practical work motivates me rather than listening all the time. (IT, NP, M, 182)

Practical ones are the best because i find myself really "doing" the work and if $i$ get stuck, i can go online and look for the information. (IT, NP, $\mathrm{M}, 164)$

Students appreciated their lecturer's efforts to motivate them in their learning with interesting and relevant content. For instance, a student from EDF1 103 commented on a podcast on motivation that he found to be particularly helpful:

Podcast on motivation, it was fully inspiring and I can listen to to it, over and over again at my leasure. (non-IT, P, M, 20)

Several students commented on the value of real-world tasks, for example:

This depends on the activity, but I find doing assignments rather than theory is much better as you are doing things as you would in the real world with real world tools. (IT, NP, M, 166)

Lessons and tasks that generate an excitement about learning were also considered to be motivating, for example:

After a fun lesson, i do find myself waiting to get home to study. A lot of the time however, motivation does play a major part towards whether study does actually happen. (non-IT, P, M, 50)

Even though only a small number of students provided text-based answers to this question, the majority of responses showed students' preferences for meaningful and authentic learning tasks that are practical, relevant, and relate to the real world.

Demotivators, as shown in Table 7, were fewer, though some of the items overlapped with the motivators, e.g., teaching styles.

Table 7: Demotivators for engaging in m-learning

\begin{tabular}{l|c|c}
\hline \multicolumn{1}{c|}{ Demotivator Themes } & $\begin{array}{c}\text { Frequency } \\
(\mathbf{N = 4 0 )}\end{array}$ & $\%$ \\
\hline Boring activities or assessment & 7 & 17.5 \\
\hline Lack of interest & 3 & 7.5 \\
\hline Teaching styles & 3 & 7.5 \\
\hline Discussion activities & 1 & 2.5 \\
\hline Group work & 1 & 2.5 \\
\hline
\end{tabular}

The major themes for demotivators showed that students were concerned about boring tasks that were not meaningful or relevant to their learning. The results also highlighted that students' lack of interest, and some teaching styles or methods may also lead to demotivation. Below are several examples of students' negative comments about whether learning activities engaged and motivated them to study. For instance, comments about boring activities:

I find them very boring and monotonous, but I will agree that they help me study. They are a good way to maintain some level of study. (IT, NP, $\mathrm{M}, 180$ ) 
Group work (discussion etc) tends to lead off target and bores me.

I prefer focussing on my own work and getting it sorted out in my mind.

I don't care what Joe Bloggs thinks..he's probably wrong.

(IT, NP, M, 165)

One student commented about the 'sameness' in assessment activities in her course:

Law assessment is the same for every unit and after a while becomes

very boring. (non-IT, NP, F, 193)

Several students also referred to their personal lack of interest or lack of motivation, for example:

... $i$ feel as though i do enough in the activites, (very lazy of me) but $i$ do

feel the need to (do more) but i don't. (IT, NP, M, 146)

I have very little motivation when it comes to uni work.

(IT, NP, F, 119)

One student commented on the potential of lectures to both motivate and demotivate depending on the teaching styles and methods used to engage learners:

Applicable to some lectures. others are completely boring and a waste of time; using poor methods of engaging students. We are doing a teaching course; surely they should practise what they preach? Make learning

ENGAGING! (non-IT, P, F, 41)

These results support the findings relating to motivators for engagement in m-learning (Table 6), highlighting the need for learning tasks to be practical, relevant to the learners and applicable to real-life.

\section{Discussion}

Understanding what motivates students to use mobile technologies is an important consideration for educators wanting to introduce new technologies into learning. The success of such initiatives could be prejudiced by attempts to use technologies in ways that are not meaningful for students and do not align with students' motivations and goals (Roblyer \& Doering, 2010). Hence, for educators the challenge is in identifying applications of mobile technologies that will contribute to achieving desirable results for students who are oriented towards performance outcomes and that will also provide a rewarding learning experience for those students who are primarily motivated by an improved learning experience or by the social aspects of learning.

From the results of this study, therefore, the main motivators for m-learning were found to be mobility, student productivity, performance outcomes, the learning experience, information access, the lecturer, authoring, entertainment and social interaction (Figure 1). 


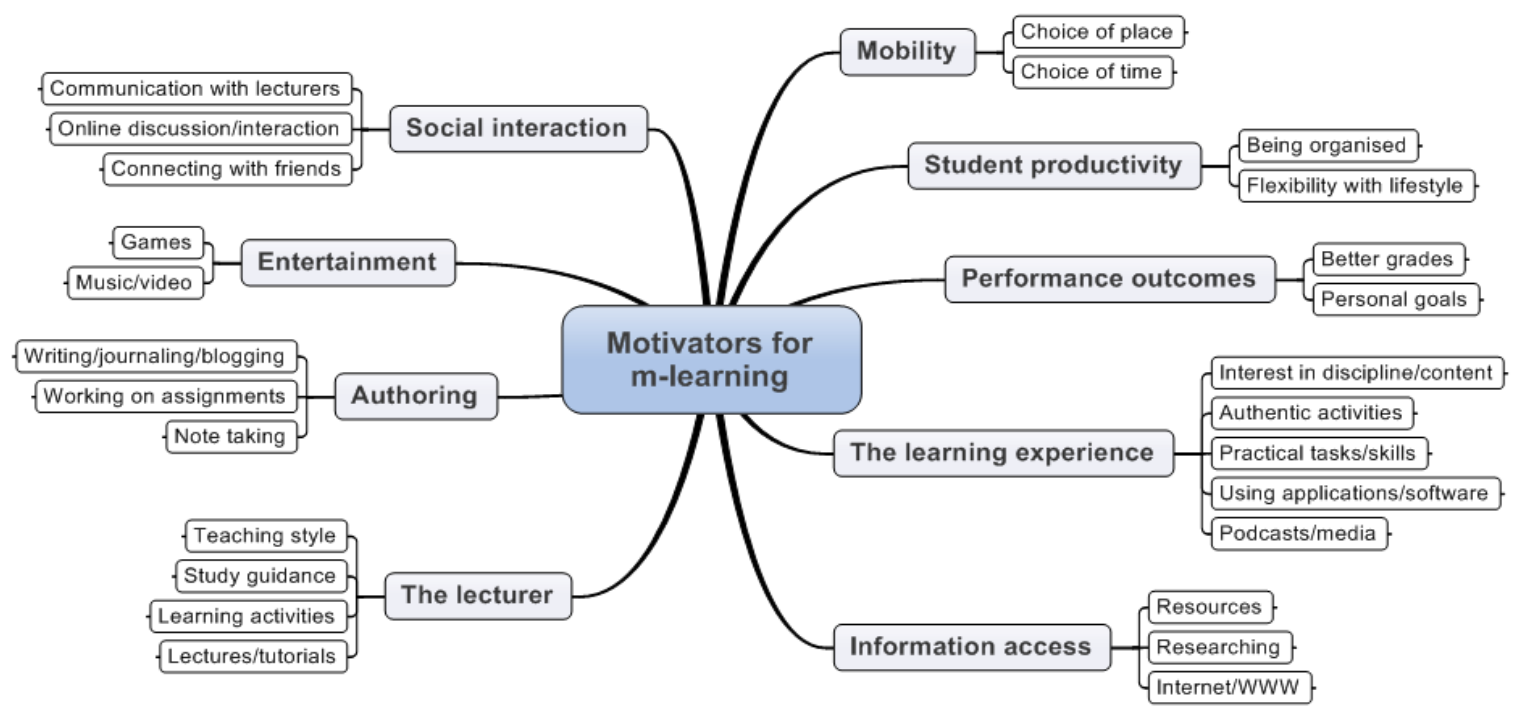

Figure 1: Motivators for m-learning

Overall, the most frequent category of motivators identified from the qualitative data was mobility, which includes having the choice of place and time for m-learning. The number of students who were motivated by performance outcomes (e.g., better grades) was small and, as expected, there were some differences between classes. For example, the law students in Class 7, who in this study were the most goal oriented and voluntarily used their laptops in class, noted that their use of laptops for learning was mainly motivated by achieving better grades and having access to learning resources. This outcome supports the findings of Breen and Lindsay (2002) that there can be subject or discipline variations in study related motivators and that not all students will be motivated by performance outcomes such as grades.

The outcomes suggest that, when planning to integrate m-learning technologies into the curriculum, it could be helpful to introduce the types of m-learning activities that students are most likely to consider motivating. For instance, lecturers could exploit the mobility and flexibility of $\mathrm{m}$-learning by encouraging students to work in informal locations (e.g., courtyards, cafes) and support m-learning by initially including students' preferred learning activities, such as sourcing information and researching, social interaction, basic authoring, or tasks with an entertainment component (e.g., video clips or educational game), thus focusing on tasks that students find to be motivating. These tasks could be followed by more challenging learning activities and assignments.

The motivators displayed in Figure 1 are a useful resource for lecturers as they show an indication of areas to focus on when developing learning designs for m-learning that will generate enthusiasm in students whilst integrating mobile technologies into learning. For example, students in this study noted that authentic learning activities that related to the real-world and practical tasks motivated them, which supports the outcomes of past studies on authentic learning tasks (Cochrane, 2008; Lee \& Lee, 2008; Olney, Herrington, \& Verenikina, 2009; Pfeiffer, Gemballa, Jarodzka, Scheiter, \& Gerjets, 2009). Aspects of the discipline or content that generate excitement about learning and prompt the understanding of new concepts were also considered by students to be motivating. This implies that students are likely to be motivated by interesting and relevant content integrated in a variety of learning designs, with some requiring interaction and group work and others requiring independent work. Ideally, educators could embed into their learning designs a range of learning activities including practical and authentic tasks and include opportunities for researching and learning about new concepts, with interactive elements where 
appropriate. Students were also motivated by productivity aspects, such as being organised, with a few commenting on being dependent on their laptop for managing their study responsibilities.

Findings from this study also indicated that lecturers' teaching styles could both motivate and demotivate students, whilst several other aspects relating to lecturers were also considered by students to be motivating (e.g., guiding, inspiring). The education students in Class 1 commented specifically on the impact of good lessons and their lecturers on their motivation to learn and, particularly, on the value of receiving clear direction as to what they need to be studying to succeed. Students in this class were also supported by podcasts on motivation designed to build an awareness of motivation in learning through metacognition, that is, becoming aware of their learning processes through reflecting on their learning. Students found these podcasts to be a helpful resource. The usefulness of podcasts for the encouragement of metacognitive thinking has been previously documented by McLoughlin, Lee, and Chan (2006).

Whilst commenting on the motivators for m-learning, students also commented on what they found to be demotivating. An encouraging finding in this study was the presence of a much greater number of motivators than demotivators for m-learning. Feedback showed that variations existed in student experiences and perceptions; therefore, the responses were not homogeneous in terms of preferences. The demotivators were mostly tasks and assessments that students found to be boring, but some students also commented that they found discussion and group work activities, in some instances, to be particularly demotivating. For several individuals, who were less keen on group work and discussion activities, this was probably due to their preference for working independently and concerns about reliance on other students for progress, as found by Waite, Jackson, Diwan, and Leonardi (2004). However, despite some negativity, most responses highlighted the motivational value of interacting with other students and communicating with lecturers. A number of students also admitted that their personal lack of interest was a major demotivator, and some also suggested that a variety in the types of learning activities should be provided to avoid boredom.

In summary, the key motivator for using laptops for m-learning was mobility. The learning tasks that were key motivators were those centred on accessing information, authoring, and communication.

\section{Conclusion}

Over the past decade, a wide range of technologies have been adopted by universities to support e-learning and blended learning, and this has resulted in more flexible learning options becoming available to students. It is not unusual for today's university students to be studying full-time, or part-time while working full-time, at the same time as having other commitments (e.g., family) and, for many, their on-campus time is limited (Conole et al., 2008; Eriksson, Vuojärvi, \& Ruokamo, 2009). Hence they need access to information, administrative systems, and learning resources 'on the run', making m-learning an attractive and practical way of conducting their studies.

This paper documents an analysis of students' motivators for m-learning and a summary of students' perceptions about m-learning. The major motivator themes that emerged from the qualitative analysis of data were mobility, study anytime, and access to learning resources. However, some aspects relating to lecturers and their teaching also had an influence in motivating or demotivating students' participation in m-learning mostly through their lecturing and teaching styles, the learning activities, and how they guided students in their studies.

According to Garrison (1997), motivation is a key dimension of self-directed learning and, in this study, students were forthcoming about what they found to be motivating, but also demotivating. Some students felt very strongly about the demotivating effect of having to undertake boring or 
monotonous tasks or having to participate in activities that do not seem to lead towards their performance outcomes or provide an enjoyable learning experience. Motivators should therefore be considered and included in the development of learning designs. Ideally, when designing an activity, lecturers could consider which aspects of the tasks are most likely to motivate their students. For example, students may be motivated by tasks with a real-life focus that they can relate to or by the use of networking tools or media that they find to be appealing. Depending on the emphasis of the activity, the learning tasks may encourage involvement in social media or a range of authentic individual or group based learning tasks.

\section{Limitations}

In this study, in some classes students' computing needs were catered for by laptop programs, and in other classes students used their own laptops or tablets. Students also used other mobile devices (e.g., iPods and smartphones) and most had access to computer laboratories on campus. However, the focus of this study was on classes where laptops or tablets were provided and classes where laptops were owned by students. Nevertheless, the study found that many students who were in laptop programs also had their own laptops, highlighting that laptop programs may be required only by some students who do not have the means to acquire a laptop.

As the research was limited to laptop/tablet users, there was no control group of non-laptop users. Therefore, when establishing the motivators and demotivators for m-learning, the findings are limited to laptop/tablet users only, which could possibly result in selection bias. The demotivators for m-learning may not all be applicable to students who do not use laptops or tablets. The demotivators for these students may be quite different (e.g., do not have access to a laptop; do not have computer skills).

\section{Practical Implications}

The findings indicated that a number of different motivators encouraged students' participation in m-learning. Some motivators centred on academic outcomes, but many motivators were related to students' learning experiences, social interaction, and the entertainment aspects of learning with technologies.

Mobility was one of the main motivators for students' use of laptops for m-learning, allowing them to study with others or alone depending on their needs at the time. Other categories of motivators identified by the students were productivity, access to information, authoring, and lecturer related motivators. Understanding what motivates students to utilise mobile technologies is an important consideration for educators wanting to introduce and meaningfully integrate new technologies into learning (Roblyer \& Doering, 2010).

Overall students did not comment any major demotivating issues with infrastructure and access to wireless networks. This result indicates that mobile learning contexts (e.g., wireless networks, computer support services) may have reached a level of maturity in Australia and economically developed countries that allows educators to move beyond focusing on establishing the facilitating conditions for mobile learning, towards a focus on learning designs, embedding m-learning in the curriculum, and creating a motivating learning environment. 


\section{References}

Boekaerts, M. (2001). Context sensitivity: Activated motivational beliefs, current concerns and emotional arousal. In S. Volet \& S. Jarvela (Eds.), Motivation in learning context: Theoretical advances and methodological implications (pp. 17-31). Oxford, UK: Elsevier Science Ltd.

Breen, R., \& Lindsay, R. (2002). Different disciplines require different motivations for student success. Research in Higher Education, 43(6), 693-725.

Cobcroft, R., Towers, S., Smith, J., \& Bruns, A. (2006, 26 September). Mobile learning in review: Opportunities and challenges for learners, teachers, and institutions. Proceedings of the Online Learning and Teaching Conference (OLT), Brisbane, Qld, Australia, pp. 21-30. Retrieved from https://olt.qut.edu.au/udf/OLT2006/gen/static/papers/Cobcroft_OLT2006_paper.pdf

Cochrane, T. (2008). Using mobile Web 2.0 to transform pedagogy and engage learners. Auckland, New Zealand: Good Practice Publication Grant e-Book. Retrieved from www.akoaotearoa.ac.nz/gppgebook

Conole, G., de Laat, M., Dillon, T., \& Darby, J. (2008). Disruptive technologies, pedagogical innovation. What's new: Findings from an in-depth study of students' use and perception of technology. Computers \& Education, 50(2), 511-524. doi: 10.1016/j.compedu.2007.09.009

Corbeil, R., Pan, C., Sullivan, M., \& Butler, J. (2007). Enhancing e-learning through m-learning: Are you ready to go mobile? In C. Crawford (Ed.), Proceedings of Society for Information Technology \& Teacher Education (SITE) International Conference 2007 (pp. 273-280). Chesapeake, VA: AACE.

Demb, A., Erickson, D., \& Hawkins-Wilding, S. (2004). The laptop alternative: Student reactions and strategic implications. Computers \& Education, 43(4), 383-401. doi: 10.1016/j.compedu.2003.08.008

de Vaus, D. A. (2002). Surveys in social research. Crows Nest, NSW, Australia: Allen \& Unwin.

Eriksson, M. J., Vuojärvi, H., \& Ruokamo, H. (2009). Laptop computers and wireless university campus networks: Is flexibility and effectiveness improved? Australasian Journal of Educational Technology, 25(3), 322-335. Retrieved from http://www.ascilite.org.au/ajet/ajet25/eriksson.html

Garrison, D. R. (1997). Self-directed learning: Toward a comprehensive model. Adult Education Quarterly, 48(1), 18-33. doi: 10.1177/074171369704800103

Gulek, J. C., \& Demirtas, H. (2005). Learning with technology: The impact of laptop use on student achievement. Journal of Technology, Learning, and Assessment, 3(2), 1-39.

Hall, M., \& Elliott, K. M. (2003). Diffusion of technology into the teaching process: Strategies to encourage faculty members to embrace the laptop environment. Journal of Education for Business, 78(6), 301-307.

Herrington, J., Herrington, A., Mantei, J., Olney, I., \& Ferry, B. (2009). Using mobile technologies to develop new ways of teaching and learning. In J. Herrington, A. Herrington, J. Mantei, I. Olney, \& B. Ferry (Eds.), New technologies, new pedagogies: Mobile learning in higher education. (pp. 1-14). Wollongong, NSW: University of Wollongong. Retrieved from http://ro.uow.edu.au/newtech/

Ingleton, C., Kiley, M., Cannon, R., \& Rogers, T. (2000). Leap into... Student-centred learning. Adelaide, SA, Australia: The University of Adelaide, ACUE. Retrieved from http://web.services.adelaide.edu.au/clpd/resources/leap/leapinto/StudentCentredLearning.pdf

Keller, J. M. (2008). First principles of motivation to learn and e3-learning. Distance Education, 29(2), 175 -185 .

Kim, S. H., Mims, C., \& Holmes, K. P. (2006). An introduction to current trends and benefits of mobile wireless technology use in higher education. AACE Journal, 14(1), 77-100.

Klein, H. J., Noe, R. A., \& Wang, C. (2006). Motivation to learn and course outcomes: The impact of delivery mode, learning goal orientation, and perceived barriers and enablers. Personnel Psychology, 59, $665-702$. 
Kuo, C.-L. (2005). Wireless technology in higher education: The perceptions of faculty and students concerning the use of wireless laptops. (Doctoral Disseration), Ohio University, Ohio, OH. Retrieved from http://etd.ohiolink.edu/etd/ (1125521504) OhioLINK Electronic Theses and Dissertations Center database.

Lane, C., \& Yamashiro, G. (2005). Educational technology at the University of Washington: Report on the 2005 instructor and student surveys (pp. 1-30). Seattle, WA: Office of Learning Technologies, University of Washington. Retrieved from http://catalyst.washington.edu/research_development/papers/2006/edtech_2005report.pdf

Laurillard, D. (2007). Pedagogical forms for mobile learning. In N. Pachler (Ed.), Mobile learning: Towards a research agenda (pp. 153-175). London, UK: WLE Centre.

Lee, Y., \& Lee, S. (2008). Situated mobile learning in higher education. In C. J. Bonk, M. M. Lee, \& T. Reynolds (Eds.), Proceedings of the World Conference on E-Learning in Corporate, Government, Healthcare, and Higher Education 2008. (pp. 1745-1750). Las Vegas, NV: AACE.

MacCallum, K. (2009, 29 September-1 October). Student characteristics and variables that determine mobile learning adoption: An initial study. Proceedings of the Universal College of Learning: Teaching and Learning Conference, Palmerston North, NZ, pp. 1-8. Retrieved from http://akoaotearoa.ac.nz/download/ng/file/group-3740/n3750-student-characteristics-and-variablesthat-determine-mobile-learning-adoption---an-initial-study---mac-callum.pdf

MacCallum, K., \& Jeffrey, L. (2009). Identifying discriminating variables that determine mobile learning adoption by educators: An initial study. In R. J. Atkinson \& C. McBeath (Eds.), Same places, different spaces. Proceedings of the 26th Annual Conference of the Australasian Society for Computers in Learning in Tertiary Education (ASCILITE 2009) (pp. 602-608). Auckland, New Zealand: ASCILITE.

MacCallum, K., \& Jeffrey, L. (2010). Resistance to the inclusion of mobile tools in the classroom: The impact of attitudes and variables on the adoption of mobile learning In R. Guy (Ed.), Mobile learning: Pilot projects and initiatives (pp. 143-166). Santa Rosa, CA: Informing Science Press.

Martin, A. J. (2006). The relationship between teachers' perceptions of student motivation and engagement and teachers' enjoyment of and confidence in teaching. Asia-Pacific Journal of Teacher Education, 34(1), 73-93. doi: 10.1080/13598660500480100

McLoughlin, C., Lee, M. J. W., \& Chan, A. (2006, 2-4 October). Fostering reflection and metacognition through student generated podcasts. Proceedings of the Australian Computers in Education Conference (ACEC 2006), Cairns, Qld, Australia, pp. 1-8. Retrieved from http://csusap.csu.edu.au/ achan/papers/2006_POD_ACEC.pdf

McMillan, K., \& Honey, M. (1993). Year one of project pulse: Pupils using laptops in Science and English. A final report. New York, NY: Center for Technology in Education. Retrieved from ERIC ED358822 http://eric.ed.gov/

Newhouse, C. P. (2001). A follow-up study of students using portable computers at a secondary school. British Journal of Educational Technology, 32(2), 209-219. doi: 10.1111/1467-8535.00191

Oblinger, D., \& Oblinger, J. L. (2005). Educating the Net Generation (pp. 264). Retrieved from http://www.educause.edu/ir/library/pdf/pub7101.pdf

Olney, I., Herrington, J., \& Verenikina, I. (2009). Digital story telling using iPods. In J. Herrington, A. Herrington, J. Mantei, I. Olney, \& B. Ferry (Eds.), New technologies, new pedagogies: Mobile learning in higher education (pp. 36-44). Wollongong, NSW, Australia: University of Wollongong.

Oloruntoba, R. (2006). Mobile learning environments: A conceptual overview. In A. Brown (Ed.), Proceedings of Learning on the Move: Online Learning and Teaching Conference 2006 (pp. 1-9). Brisbane, Qld, Australia: Queensland University of Technology.

Pfeiffer, V. D. I., Gemballa, S., Jarodzka, H., Scheiter, K., \& Gerjets, P. (2009). Situated learning in the mobile age: Mobile devices on a field trip to the sea. ALT-J: Research in Learning Technology, 17(3), $187-199$. 
Pintrich, P. R. (2003). A motivational science perspective on the role of student motivation in learning and teaching contexts. Journal of Educational Psychology, 95(4), 667-686.

Pintrich, P. R., \& Schunk, D. H. (2002 ). Motivation in education: Theory, research, and applications. (2nd ed.). Michigan, MI: Merrill.

Prensky, M. (2001). Digital Natives, Digital Immigrants. On the Horizon, 9(5), 1-6.

Roberts, G. R. (2005). Technology and learning expectations of the Net Generation. In D. Oblinger \& J. Oblinger (Eds.), Educating the Net Generation. (pp. 3.1-3.7). Boulder, CO: EDUCAUSE.

Roblyer, M. D., \& Doering, A. H. (2010). Integrating educational technology into teaching (5th ed.). New York, NY: Allyn \& Bacon.

Sha, L., Looi, C. K., Chen, W., \& Zhang, B. H. (2012). Understanding mobile learning from the perspective of self-regulated learning. Journal of Computer Assisted Learning, 28(4), 366-378. doi: $10.1111 / \mathrm{j} .1365-2729.2011 .00461 . \mathrm{x}$

Schunk, D. H., Pintrich, P. R., \& Meece, J. L. (2008). Motivation in education: Theory, research, and applications. (3rd ed.). Upper Saddle River, NJ: Pearson.

Seifert, T. L., \& O'Keefe, B. A. (2001). The relationship of work avoidance and learning goals to perceived competence, externality and meaning. British Journal of Educational Psychology, 71(1), 81-92. doi: $10.1348 / 000709901158406$

Traxler, J. (2009). Learning in a mobile age. International Journal of Mobile and Blended Learning, 1(1), $1-12$.

Waite, W. M., Jackson, M. H., Diwan, A., \& Leonardi, P. M. (2004). Student culture vs group work in computer science. ACM SIGCSE Bulletin, 36(1), 1-16. doi: 10.1.1.4.7900

Wolters, C. A. (2004). Advancing achievement goal theory: Using goal structures and goals orientations to predict students' motivation, cognition, and achievement. Journal of Educational Psychology, 96, 236250.

Wolters, C. A., Yu, S. L., \& Pintrich, P. R. (1996). The relation between goal orientation and students' motivational beliefs and self-regulated learning. Learning and Individual Differences, 8(3), 211-238. doi: http://dx.doi.org/10.1016/S1041-6080(96)90015-1 


\section{Biographies}

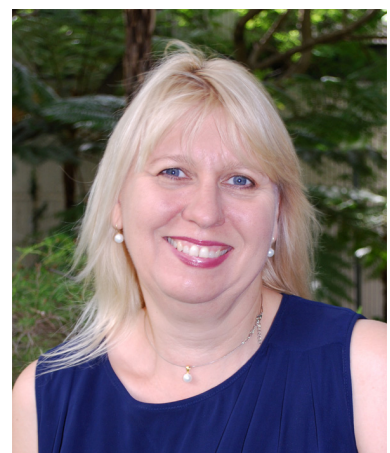

Romana Martin is a Lecturer in the Teaching and Learning team at the Curtin Business School at Curtin University in Western Australia. Her qualifications include a MEd from Edith Cowan University and a $\mathrm{PhD}$ from Murdoch University in Western Australia. Her background is in the field of educational design, academic development and educational technology and she has multidisciplinary qualifications in education, information technology and educational multimedia. In her current role she provides academic leadership and expertise in online and blended learning and the application of new technologies to support student learning. She has led a wide range of teaching and learning initiatives and her research interests are in the field of online learning, mobile learning, student engagement, student-centered learning and new generation learning spaces.

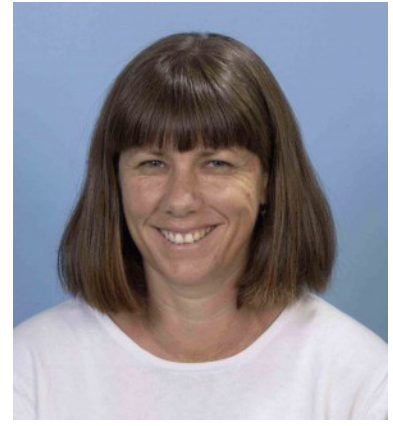

Tanya McGill is an Associate Professor in the School of Engineering and Information Technology at Murdoch University in Western Australia. She has an MBA from the University of Western Australia and a $\mathrm{PhD}$ from Murdoch University. Her major research interests include elearning, technology adoption, and information technology education. She is the author of over 100 journal articles, book chapters, and articles in conference proceedings. Her research has been published in various journals including Behaviour and Information Technology, Decision Support Systems, Computers \& Education, Journal of Computer Assisted Learning, ACM Transactions on Information and System Security, Journal of Computing in Higher Education, and Information Resources Management Journal.

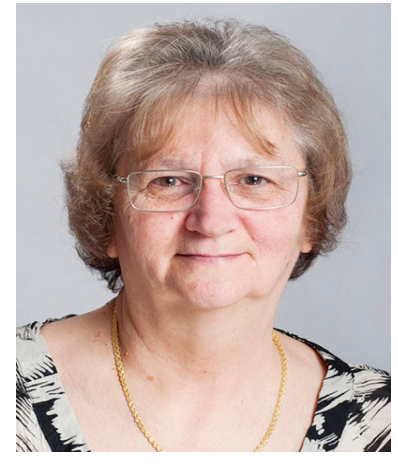

Fay Sudweeks is Emerita Associate Professor at Murdoch University and former Adjunct Associate Professor at the Australian National University. She has a Bachelor of Arts (Psychology and Sociology), Master of Cognitive Science and Doctor of Philosophy (Communication Studies). Her current research interests are e-learning and the social, cultural and economic aspects of computer-mediated communication. She has published an authored book, 8 edited books, 10 edited proceedings, and more than 80 papers in journals, books and conference proceedings. She is on the editorial board of the Journal of Computer-Mediated Communication, New Media and Society, International Journal of e-Learning, and Human Communication Research. With Charles Ess, she has co-chaired five international and interdisciplinary conferences on Cultural Attitudes towards Technology and Communication. 